Crop Breeding and Applied Biotechnology 13: 1-8, 2013

Brazilian Society of Plant Breeding. Printed in Brazil

PLANT BREEDING PROGRAM

\title{
Development of cold and drought tolerant short-season maize germplasm for fuel and feed utilization
}

\author{
Marcelo J Carena ${ }^{1 *}$ \\ Received 13 October 2012
}

Accepted 18 December 2012

\begin{abstract}
Maize has become a profitable alternative for North Dakota (ND) farmers and ranchers. However, U.S. northern industry hybrids still lack cold and drought stress tolerance as well as adequate grain quality for ethanol and feedstock products. Moreover, there is a need to increase the value of feedstock operations before and after ethanol utilization. The ND maize breeding program initiated the development of hybrids with high quality protein content through the Early Quality Protein Maize for Feedstock (EarlyQPMF) project. The North Dakota State University (NDSU) maize breeding program acts as a genetic provider to foundation seed companies, retailer seed companies, processing industry, and breeders nationally and internationally. In the past 10 years, NDSU was awarded 9 PVP maize certificates and released 38 maize products. Within those, 13 inbred lines were exclusively released to a foundation seed company for commercial purposes. In addition, 2 hybrids were identified for commercial production in central and western ND.
\end{abstract}

Key words: North Dakota, ethanol, high quality protein content.

\section{INTRODUCTION}

Applied plant breeding is the science of efficient cultivar development with an end practical use. Plant breeding is a science of evolution (Hallauer et al. 2010) and it is a discipline that has evolved with the development of human societies (Hallauer and Carena 2009). Many traits, especially those of quantitative inheritance with difficult phenotyping, are involved in the process of developing improved cultivars for climate changes (Carena 2011). Applied plant breeding is the best investment to maintain enough food supply under the environmental challenges (e.g., low temperatures, drought, flood, salinity, global warming, biofuel demand, etc.) facing our planet.

Plant breeding has been presented as the discipline that 'feeds the world'. In fact, many researchers, farmers, public leaders, and plant breeding organizations have often accepted and promoted this concept. Plant breeding has been the source of food and the defense over hunger for centuries but it also has been and continues to be a very profitable business. Breeders have been able to accelerate evolution on to their favor and produce more food in less area contradicting those that predicted human catastrophes due to the increase of world human population. Even today, an increasing world population is not a threat for hunger, rather a potential for economic prosperity. Unfortunately, although plant breeding and human population are only two factors in the puzzle of world problems and solutions, plant breeding alone cannot 'feed the world' without economic and political changes in world food distribution systems as well as in world population consumption and distribution patterns. We need to recognize a world that often puts economic priorities over hunger problems in different areas of the same world we live in. Moreover, having more production than needed is known to have caused economic problems conducing to reduced commodity prices and influencing harvests to be lost on purpose, part of the difficult truth of the world we live in.

There is still enough food for an increasing world population even if the largest proportion of maize production ends up for fuel and feedstock instead of feeding human populations. Economically, adequate food distribution is still a challenge to alleviate hunger and malnutrition, the major problems facing the modern $21^{\text {st }}$ century. In 2008, the World Food and Agricultural Organization (FAO) stated 'millions of people have the right to access to adequate food'. Still, plant breeding continues to be, if wisely applied, the best investment to maintain enough food supply under climate changes (Carena 2009). Leaving politics aside, sharing

${ }^{1}$ North Dakota State University, Department of Plant Sciences, Dept. \# 7677, Fargo, ND 58108-6050, USA. *E-mail: marcelo.carena@ndsu.edu 
elite germplasm and the know-how on effective breeding techniques can make any community sustainable while coexisting with profitable businesses, especially if crop value is added. Ethanol high quality byproducts, for instance, can significantly reduce the amount of maize used for feedstock.

The North Dakota State University (NDSU) maize breeding program has gained unique support from private companies, trade organizations, and the farmer producers, which were reflected in the response to maize production in North Dakota (ND). There has been a significant increase in the ND maize area and productivity displacing small grains in the region. On average, a very short period between killing frosts, a low effective heat supply as we move north, and a low average rainfall as we move west, are the ND climate challenges breeders have used as opportunities to direct evolution faster. These opportunities have often been neglected by simply testing lines and hybrids developed in southern Minnesota (MN), which makes evolution slower. Still, billions of dollars are being lost to drying drought and cold susceptible maize, and to processing low quality grain in the northern U.S. market.

The NDSU maize breeding program is known for being the most northern public corn breeding program in North America moving unique and diverse elite maize north to cooler seasons and west to drier areas. Therefore, exploiting ND environments through summer and winter nurseries and summer multi-location trials have achieved several degrees of cold and drought tolerance in addition to yield improvement.

Enhancement of traits that provide added value to the maize crop has been slow due to a market that still does not provide a deserved value to grain quality. One important objective in breeding for grain quality is the increase of the amount of extractable starch that can be recovered from maize kernels for milling processes. Maize with high extractable starch could increase grower premiums significantly. Careful drying and the availability of short-season maize with fast dry down (Yang et al. 2010) are essential for achieving high levels of extractable starch. Improvement in seed genetics through short-season maize breeding programs focused on more starch per acre has the potential to make the greatest impact especially under abiotic stresses.

Although cereals are very important for food and are the basic diet for the world population, they are poor in the nutritional protein value. Cereals are not only the most important energy source but also they are the most important protein source in the world. They provide around $50 \%$ of the dietary protein for humans and can comprise $70 \%$ of the protein intake for people in the southern hemisphere (Habben et al. 1995). Unfortunately, the most abundant proteins in them are devoid of essential amino acids. A primary limitation of maize grain is its inability to satisfy the essential amino acids needed to meet the nutritional requirements of mono gastric animals and humans (Scott et al. 2004).

Improving maize quality under ND challenging environmental conditions has been one of the long-term goals of the NDSU maize breeding program to add short-season maize value for feed and fuel. Starch traits have been used to improve ethanol efficiency while essential amino acids have been the traits used to improve protein quality. NDSU conducts maize breeding for high extractable starch under drought and cold stresses as well as for high quality protein and fast drying maize to develop the next generation of healthier and safer products.

\section{Breeding short-season products with abiotic stress tolerance}

Adaptation to climate changes requires improvement of traits that are quantitatively inherited largely influenced by the environment. These traits are often controlled by hundreds of genes and their interactions, which are difficult to measure. Ideas to overcome the evaluations of such traits should be a priority. The MN and ND Corn Grower Organizations have been essential to support the idea of winter nursery controlled environments for screening maize early generation products for drought and cold tolerance. Cold tolerance efforts have allowed us to make progeny selection progress at a rate of one season per year identifying progenies with high levels of cold tolerance (Sezegen and Carena 2009). The identification of screening locations (e.g., high Montana elevations with snow and frost in July; as well as southern Argentina and New Zealand winter nursery cold-managed environments) have allowed us to identify cold tolerant products currently demanded and utilized by industry at a very efficient rate of three to four seasons per year.

We have utilized hundreds of progenies for recurrent selection in genetically-broad based populations (e.g. Montana locations). However, samples sizes have been largest for inbred line development. Over 5200,000 individuals and progenies are grown annually in summer and winter breeding nurseries. The most vigorous and outstanding progenies are harvested and immediately planted in our first winter nursery, the shortseason cold tolerance winter nursery (e.g., planted in early September). Screening of thousands of lines at different levels of inbreeding is performed under controlled winter nursery conditions with extensive screening for emergence and vigor. Several hectares are annually planted in the southern hemisphere summers during the northern hemisphere winters in leveled uniform fields with access to irrigation. Two sets of data are collected for emergence percentage (early and late emergence percentage) and three sets of data are collected 
for seedling vigor. A rank-summation index is applied for both traits to select the most early season cold tolerant lines. Discard rates have ranged from $30 \%$ to $40 \%$ across winter seasons. Best lines from each pedigree background are kept and surviving lines are crossed to industry testers in our second winter nursery, the short-season production winter nursery (e.g. planted in early November) for hybrid combinations and testing in northern ND and MN environments (e.g., planted in early May). Therefore, selection is based not only on exposure of inbred lines to cold stress under controlled winter environments but also based on hybrids on target northern U.S. environments. Progenies selected in 2012 were already shipped to the southern hemisphere and planted on September 9, 2012 when hard early frosts are still possible. Very long rows are utilized to fully represent genotypes. Also, screening for drought and heat tolerance in winter nurseries is focused on the maize flowering and grain filling stages. Further information on the methods utilized by the NDSU maize breeding program can be found in Carena et al. (2009b) and Hallauer et al. (2010). In 2012, the NDSU maize corn program planted 36 experiments across $>20$ locations for breeding purposes. Most industry hybrids, used as checks, and available in the northern U.S. market have demonstrated not to be locally bred for the northern USA but NDSU inbred line releases have helped reduce these problems (Table 1). These lines have not been registered nationally due to exclusive agreements recently established with Foundation Seed Companies.

The NDSU maize breeding program adapted unique temperate and tropical genetic materials to ND environments in order to increase the genetic diversity of northern U.S. hybrids (Carena et al. 2009a). Utilizing exotic germplasm was successful not only to improve grain quality components but also to improve grain yield, lodging resistance, and test weight under non-marginal ND environments and intermediate relative maturities. Only with the utilization of genetically broad-based germplasm one can only expect highly significant improvements in genetic gain (Carena 2012).

Unique NDSU exotic hybrids also showed high stability on dry land and irrigated experiments within the same environments. Ranks of NDSU and industry hybrids clearly showed a difference in stability. However, short-season transgenic drought-tolerant industry products have not yet been included as checks in our experiments as they still are not offered in this market. Significant large differences for grain moisture at harvest and starch content were found in one of the top NDSU exotic hybrids bred for ethanol utilization and cold tolerance when compared to industry checks. In addition, one of NDSU most elite hybrids showed excellent results for grain quality under cold and drought stresses as well as for better protein quality. As a consequence, the experimental NDSU exotic line used in this hybrid was exclusively released in 2012.

NDSU has provided unique and diverse genetic maize products under different intellectual property systems across decades. In the 1990s, following the direction of most universities across the nation, ownership of public NDSU products was transferred from the ND Agriculture Experiment Station (NDAES) to the NDSU Research Foundation (NDSURF) with the objective to protect public products developed at NDSU. As a consequence, seed source distribution was restricted and intellectual protection of maize public products followed through numerous agreements (e.g. Material Transfer, Inbred Research, Commercialization agreements, etc.). Public breeders, at the same salary level, had to include in their research portfolio Plant Variety Protection (PVP), DNA fingerprinting, and restrictions to germplasm exchange pending administration approval. Even with these limitations releases were quick and access was equal to all interested institutions (Carena and Wanner 2003, Carena et al. 2003, Carena et al. 2008, Carena and Wanner 2009, Carena et al. 2010). In addition, breeder seed increases required few nursery rows and a $\$ 500$ fee was established per request which was created to be used in full by breeding program needs. In 2009, however, in an attempt to track NDSU maize confidential

Table 1. Maize inbred lines released at NDSU during 2010-2012 (adapted from Carena 2012)

\begin{tabular}{l|lll}
\hline $\begin{array}{l}\text { Release } \\
\text { Code }\end{array}$ & $\begin{array}{l}\text { Heterotic } \\
\text { Group }\end{array}$ & Genetic Background & $\begin{array}{l}\text { Relative } \\
\text { Maturity }\end{array}$ \\
\hline ND47 & SS & Elite x elite SS & 95-100RM \\
ND290 & non-SS & NDSM(M)C1 & 75-80RM \\
ND2007 & SS \& non-SS & Elite SS x non-SS & 95-100RM \\
ND2008 & non-SS & NDBS21(R)C7 & $90-95 R M$ \\
ND2009 & SS \& non-SS & Elite SS x non-SS & $90-95 R M$ \\
ND2010 & SS \& non-SS & NDBS22(R-C)C7 & $90-95 R M$ \\
ND2011 & non-SS & NDEarlySS(S)C5 & $75-80 R M$ \\
ND2012 & SS & NDSUEarlyGEM & $85-90 R M$ \\
ND2013 & SS \& non-SS & NDBS1011(M-S)C4 & $90-95 R M$ \\
ND2014 & SS & NDSUEarlyGEM & $85-90 R M$ \\
ND2015 & SS & NDSUEarlyGEM & $85-90 R M$ \\
ND2016 & SS \& non-SS & NDSUEarlyGEM(HR) & $85-90 R M$ \\
ND2017 & non-SS & Elite Lanc. x ND278 & $90-95 R M$ \\
ND2018 & non-SS & NDSUEarlyGEM & $85-90 R M$ \\
ND2019 & non-SS & NDSUEarlyGEM & $85-90 R M$ \\
ND2020 & SS & NDSCD(M)C8 & $80-85 R M$ \\
ND2021 & SS & NDEarlySS(S)C5 & $75-80 R M$ \\
\hline
\end{tabular}

SS: Stiff Stalk; M: mass selection, R: reciprocal recurrent selection, S: inbred progeny recurrent selection; C: cold tolerance; HR: heat and drought resistance under both dry land and irrigated environments 
products and recover royalties, releases became exclusive to institutions. As a consequence, exclusive partners became the marketing arms of NDSU but one condition of this exclusivity was to give institutions years of advantage before a product could be registered publicly. Therefore, none of the products released in the past five years have been registered through the national CSSA system but they have been re-coded in order to access the commercial arena. Therefore, NDSU has become an official genetic provider of unique inbred lines to foundation seed companies who sell their products to retailer companies across regions. However, NDSU products often go to southern MN instead of going north as foundation seed companies are still not present in the north. Retailer companies are the ones selling seed directly to the farmer, which buy and license lines and hybrids offered in southern MN.

The U.S. maize public and private sectors currently suffer from their own intellectual property limitations and controlling systems. In fact, public breeders have, in certain cases, lost control of release procedures which have often either reduced the efficiency of the process or have been the source of avoidable technical mistakes. Royalties are perceived as the solution for basic and applied scientific products developed in the public sector within a confidential market (e.g. controlling breeding rights and limiting breeding access). However, these approaches limit developing the ultimate product for farmers. Public-private partnerships to develop the next generation of maize products are encouraged. The ideal hybrid for northern U.S. farms is still missing due to intellectual property limitations (Carena 2012).

Preliminary data for useful exotic germplasm were validated when comparing northern U.S. industry hybrids with tropical and temperate hybrids adapted to ND conditions through the NDSU EarlyGEM program (Carena et al. 2009a). Industry hybrids bred in southern $M N$ and sold in northern ND and MN are often unstable with late maturity, slow dry down, and very poor grain quality. On the other hand, hybrids developed with exotic lines adapted to northern ND and MN conditions were successfully adapted. In 2012, the NDSU corn breeding program planted 36 experiments across $19<20$ locations. The number of hybrid experiments was significantly increased across northern locations. The 2012 drought year gave us a good opportunity to select stable short-season lines and hybrids with not only cold but also drought tolerance in northern ND and MN. Only later planted hybrids were able to escape the severe drought that affected the region. Nevertheless, NDSU tropical adapted products are expressing unique genes for cold and drought tolerance already and we expect similar genes for above average grain quality, ethanol utilization, and fast dry down, which will break environmental margins. These products will increase the variation $(63.7 \%$ to $66.8 \%)$ reported for starch yield (Lambert and Ecknoff 1999). The large-scale volumes at which the industry operates make minimal variations (e.g., even $1 \%$ of extractable starch) to be highly significant.

Still, few industry inbred lines are viable for northern U.S. maize production as quoted from small industry cooperators. In addition to selecting for higher grain quality under cold stress, selecting hybrids for fast dry down has been essential. The NDSU maize breeding program has been recognized for developing a scientific and practical method toward helping save billions of dollars to drying maize through the development of short-season faster drier maize lines and hybrids. NDSU validated its discovery (AUDDC-area under the dry down curve) on screening maize inbred lines and hybrids for fast dry down (Yang et al. 2010). This can reduce grower's production cost related to artificial grain drying. Annually, the upper Midwest consumes more than $\$ 1.4$ billion of fossil fuels to dry $\$ 19.7$ billion of corn maize grain. Public and private institutions have already taken advantage of this method developed at NDSU. This method has demonstrated to be accurate and reliable; and three major companies are already utilizing it.

\section{Breeding efforts toward high quality protein products}

The most serious limitation for the efficient use of maize grain as a food source, both for animal and human consumption is its poor nutritional quality. Breeding maize for better protein quality can solve nutrition problems in humans as well as in animals. Thus, the goal of breeders would be to develop new varieties with good nutritional and productive value. This is not an easy task since normally higher yields are correlated with lower protein content. Besides, high protein content is not often correlated with desirable amino acid contents. However, the use of large screening samples has shown, in our program, that associating opposite traits is possible.

The proteins generally found in maize endosperm lack the amino acid balance necessary for good growth. Zein is the major component of maize endosperm representing 60$70 \%$ of normal total maize endosperm protein (Lund et al. 1995), but is devoid of essential amino acids. The $\mathrm{O}_{2}$ gene is a mutant first described by Singleton and Jones in the early 20 's and located in the short chromosome \#7 of the maize genome (Lopes and Larkins 1995). The importance of the mutant resides in the discovery done by Mertz et al. (1964). They observed that the maize mutation causes a reduction in the synthesis of zein and the formation of a soft, starchy endosperm in the seed. These authors also encountered that the mutant seeds contained twice the normal concentration of the essential amino acid lysine. Habben et al. (1993) also 
reported that the reduction of zein protein synthesis is associated with an increased percentage of lysine in the endosperm. The potential use of opaque- 2 maize has been hampered by its poor agronomic performance. Plant breeders have made a big effort to improve the nutritional quality of maize with the opaque- 2 gene but pleiotropic effects associated with this mutation, however, have resulted in seeds with inferior agronomic properties (Vasal 1994, Lopes and Larkins 1995). Modifier genes have been described that convert the soft, starchy endosperm of mutants to a hard, vitreous (hard and translucent) phenotype, while maintaining the enhanced lysine content of the grain. This conversion occurs naturally in certain maize genotypes (Lopes et al. 1995) and the genes that condition this change are generally called opaque- 2 modifiers. Modified genotypes, which resemble normal maize, both in kernel phenotype and agronomic performance, are known as Quality Protein Maize (QPM) genotypes. CIMMYT is one of the institutions that yielded a broad array of QPM germplasm adapted to tropical and subtropical areas. Their work initially emphasized the conversion to $\mathrm{O}_{2}$ genotypes of various genetically broad based germplasm pools, which were subsequently improved by breeding programs that included backcrossing and recurrent selection (Pixley and Bjarnason 1993). As a consequence, vitreous kernels and agronomic performance similar to normal-endosperm maize were achieved by accumulating modifier genes (Vasal et al. 1980). Gupta et al. (1975) suggested that line selection with this characteristic may be important for the production of improved QPM hybrids. South Africa developed QPM hybrids with higher yields than the best hybrids used in that region. Some of the initial problems have been solved. The grain phenotype has been improved and yield was expressed because the more accumulation of dry matter in grain. QPM hybrids are more resistant to insects and mold during storage and they keep the protein quality. However, adaptation of QPM genotypes to temperate environments and higher latitudes has been challenging.

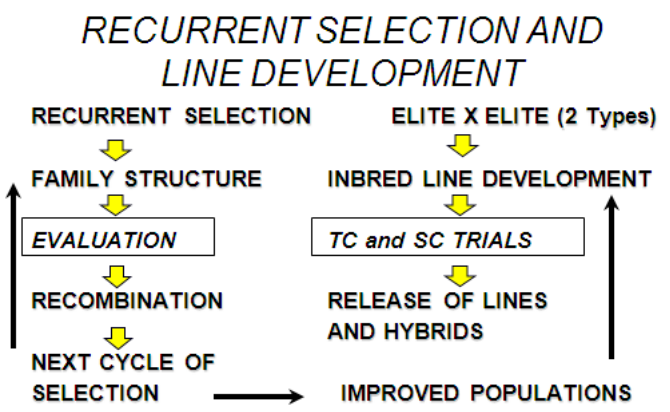

The NDSU maize breeding program was the first program to initiate efforts to adapt QPM genotypes to the northern U.S. and to extensively evaluate elite and adapted populations for amino acid composition. Fifty QPM temperate genotypes were acquired. $\mathrm{F}_{1}$ crosses and backcrosses were produced between QPM genotypes and elite early-maturing germplasm in the 2010 and 2011 Fargo breeding nurseries. Crosses between earliest males and late females were conducted and males flowering 10 or more days later than the recurrent parent were discarded. Thousands of $\mathrm{BC}_{1}: \mathrm{S}_{1}$ lines representing at least two heterotic groups were produced in the 2012 Fargo breeding nursery and are being test-crossed with industry testers representing opposite heterotic groups in the 2012-2013 winter nursery. Best lines will be used to recombine and create new QPM synthetic varieties for genetic improvement through recurrent selection and will be advanced for additional test-crossing and late-generation testing. This is one of NDSU corn maize projects representing the new NDSU EarlyQPMF program to adapt high quality protein products for feedstock and ethanol byproduct uses.

\section{CONCLUSIONS}

The NDSU maize breeding program integrates germplasm adaptation and improvement with cultivar development (Figure 1) to develop the next generation of drought and cold tolerant short-season products with increased grain quality. In the past five years, we have received 890 inbred line requests carrying with yield and earliness, cold and drought tolerance, fast dry down, green snap and stay green tolerance, quality, and especially unique genetic diversity. This diversity from this short-season germplasm is not present in the B73 line and/or the Nested Association Mapping (NAM) population genomes in the past 5 years. One particular line (e.g. ND2000) provided significant funds for operating and salary funds needs.

New projects are in the research pipeline, the NDSU EarlyQPM and the NDSU Early QPMF programs, are becom-

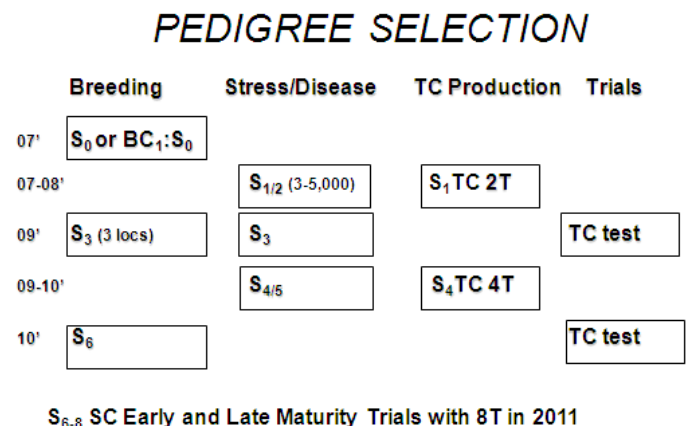

Figure 1. Integration of germplasm adaptation and improvement with corn cultivar development at NDSU. 
ing ready following the successful adaptation of tropical and late temperate products conducted by the NDSU EarlyGEM program (Carena et al. 2009a). In the past three years, 35\% of NDSU corn releases were derived from this specific adaptation program increasing the genetic diversity of northern U.S. hybrids. Public-private partnerships with full germplasm exchange and breeding access for breeding purposes are encouraged. as The ideal hybrids for maize corn farmers are is still missing due to intellectual property limitations.

Public breeding programs should continue to plan longterm visionary goals, apply innovative ideas with continuous research, and discriminate among 'cutting edge' research often done by most scientists. The need for infrastructure and personnel in public breeding programs are not very popular among grant donors but are needed to formulate unique ideas before pursuing funding. Few extensive recurrent selection programs are left that could validate models for proposed selection methodologies such as genome-wide selection (Bernardo and Yu 2007) or increase the sample sizes utilized in mapping studies through classic mating designs (Carena and Wicks III 2006, Bernardo 2008, Hallauer and Carena 2009).

Adaptation to abiotic stresses requires improvement of traits quantitatively inherited largely influenced by the environment. These traits are often controlled by hundreds of genes and each hybrid has its own specific gene combinations (Hallauer and Carena 2009), which are often difficult to measure. Ideas to overcome the evaluation of such traits should be a priority (Yang et al. 2010). Targeting these traits with newer technologies based on their genetic and practical complexity (e.g., maize flowering vs. maize roots) should be the first goal for basic and applied science projects (Yang et al. 2010, Carena 2012). The U.S. Science Foundation (NSF) and the U.S. Department of Agriculture (USDA) have spent millions of dollars targeting genetically simple traits (e.g. maize flowering), sequencing genetically narrow-based genotypes not representing unique and diverse alleles, or trying to explain, in theory, methodologies with applied impact. Molecular markers were originally proposed to solve breeding challenges with quantitative traits with challenging phenotyping. Besides, active cooperation with industry should provide access to latest technology without having to invest in obsolete academic labs (Guimaraes et al. 2006). There is a need to target newer technologies on traits that are genetically complex, difficult to measure, and carry unique alleles based on maximum sampling. Breeding programs should develop not only products but also applied breeding methodologies accurately screening thousands of genotypes fast. These considerations will fill the gap between geneticists, physiologists, and breeders to develop the next generation of products with maximum efficiency. Breeding programs should adapt, improve, and develop elite and unique germplasm through most efficient (old and new) breeding strategies depending on cost and impact. Stratified mass selection (Gardner 1961), for instance, haves been extremely successful (making maize products 2-4 days earlier per year independent from genotype) and very cost/effective for adapting genetic materials to northern latitudes in the U.S. by utilizing large samples and selecting for earliness visually (Hallauer and Carena 2009).

Controlling winter nursery locations for abiotic stresses (Carena et al. 2009b) complemented with not only testing in target environments but also breeding under stress have resulted in successful product development under challenging environmental conditions. Maize research, development, and production in marginal regions will continue to lead breeding research for climate changes worldwide. These will be the source of cultivars and breeding methods that will meet the $21^{\text {st }}$ demands of food, feed, fuel, and fiber. Hybrid corn today, for instance, is the same methodology that has been used for maize corn production in the early 1900s. When will the next successful maize breeding methodology happen for commercial purposes?

\title{
Desenvolvimento de germoplasma de milho precoce, tolerante ao frio e a seca para produção de energia e alimentação animal
}

\begin{abstract}
Resumo - Milho se tornou uma alternativa rentável para os agricultores e pecuaristas de North Dakota (ND). No entanto, os híbridos desenvolvidos pela indústria do Norte dos EUA ainda não têm tolerância ao frio e a seca, bem como não tem a adequada qualidade do grão para produtos como etanol e alimentação animal. Portanto, é necessário aumentar o valor das operações de alimentação animal antes e depois da utilização do etanol. O programa da North Dakota State University (NDSU) iniciou o desenvolvimento de hibridos que apresentem alto conteúdo de proteina através do projeto de milho precoce com alto conteúdo de proteina de qualidade (EarlyQPMF). O Programa da NDSU atua como um fornecedor genético para empresas de sementes básicas, companhias varejista de sementes, indústria de processamento, e melhoristas, nacionais e internacionais. Nos últimos 10 anos, NDSU obteve nove certificados de proteção (PVP) de milho e lançou 38 produtos de milho. Dentro desses, 13 linhagens foram lançadas, exclusivamente, para uma empresa de sementes básicas para fins comerciais. Alem disso, dois híbridos foram identificados para a produção comercial na região central e ocidental de North Dakota.
\end{abstract}

Palavras-chave: North Dakota, etanol, alto conteúdo de proteina de qualidade. 


\section{REFERENCES}

Bernardo R (2008) Molecular markers and selection for complex traits in plants: Learning from the last 20 years. Crop Science 48:1649-64.

Bernardo B and Yu J (2007) Prospects for genome-wide selection for quantitative traits in maize. Crop Science 47: 1082-90.

Carena MJ (2009) Handbook of plant breeding: cereals. Springer, New York, $425 \mathrm{p}$.

Carena MJ (2011) Germplasm enhancement for adaptation to climate changes. Crop Breeding and Applied Biotechnology S1: 56-65.

Carena MJ (2012) Challenges and opportunities for developing maize cultivars in the public sector. Euphytica (accepted).

Carena MJ and Wanner DW (2003) Registration of ND2000 inbred line of maize. Crop Science 43: 1568-1569.

Carena MJ and Wanner DW (2009) Development of genetically broadbased inbred lines of maize for early maturing (70-80RM) hybrids. Journal of Plant Registrations 3: 107-111.

Carena MJ and Wicks III ZW (2006) Maize early maturing hybrids: an exploitation of U.S. temperate public genetic diversity in reserve. Maydica 51: 201-208.

Carena MJ, Eno C and Wanner DW (2008) Registration of NDBS11(FR-M) C3, NDBS1011, and NDBSK(HI-M)C3 maize germplasms. Journal of Plant Registrations 2: 132-136.

Carena MJ, Wanner DW and Cross HZ (2003) Registration of ND291 inbred line of maize. Crop Science 43: 1568.

Carena MJ, Wanner DW and Yang J (2010) Linking pre-breeding for local germplasm improvement with cultivar development in maize breeding for short-season (85-95RM) hybrids. Journal of Plant Registration 4: 86-92.

Carena MJ, Pollak L, Salhuana W and Denuc M (2009a) Development of unique lines for early-maturing hybrids: Moving GEM germplasm northward and westward. Euphytica 170: 87-97.

Carena MJ, Bergman G, Riveland N, Eriksmoen E and Halvorson M (2009b) Breeding maize for higher yield and quality under drought stress. Maydica 54: 287-296.

Gardner CO (1961) An evaluation of effects of mass selection and seed irradiation with thermal neutrons on yield of corn. Crop Science 1: 241-245.

Guimaraes E, Kueneman E and Carena MJ (2006) Assessment of national plant breeding and biotechnology capacity in Africa and recommendations for future capacity building. Horticultural Science 41: 50-52.

Gupta D, Kovacs I and Gaspar L (1975) Protein quality traits and their relationships with yield and yield components of opaque- 2 and analogous normal maize hybrids and inbred lines. Theoretical and Applied Genetics 45: 341-348.
Habben JE, Kirleis AW and Larkins BA (1993) The origin of lysinecontaining proteins in opaque-2 maize endosperm. Plant Molecular Biology 23: 825-838.

Habben JE, Moro GL, Hunter BG, Hamaker BR and Larkins BA (1995) Elongation factor $1 \alpha$ concentration is highly correlated with the lysine content of maize endosperm. Proceedings of the National Academy Science of the United States of America 92: 8640-8644.

Hallauer AR and Carena MJ (2009) Maize breeding. In Carena MJ (ed.) Handbook of plant breeding: cereals. Springer, New York, p. 3-98.

Hallauer AR, Miranda Fo JB and Carena MJ (2010) Quantitative genetics in maize breeding. $3^{\text {rd }}$ ed., Springer, New York, 663p.

Lambert RJ and Eckhoff S (1999) Pilot wet-milling evaluations of commercial corn hybrids. In Hallauer AR (ed.) North central corn breeding research committee report. Ames, p. 17-20.

Lopes MA and Larkins BA (1995) Genetic analysis of opaque-2 modifier gene activity in maize endosperm. Theoretical and Applied Genetics 19: $274-281$.

Lopes MA, Takasaki K, Bostwick DE, Helentjaris T and Larkins BA(1995) Identification of two opaque-2 modifier loci in Quality Protein Maize. Molecular and General Genetics 247: 603-613.

Lund G, Ciceri P and Viotti A (1995) Maternal-specific demethylation and expression of specific alleles of zein genes in the endosperm of Zea mays L. The Plant Journal 8: 571-581.

Mertz ET, Bates LS and Nelson OE (1964) Mutant gene that changes protein composition and increases lysine content of maize endosperm. Science 145: 279-280.

Pixley KV and Bjarnason MS (1993) Combining ability for yield and protein quality among modified endosperm opaque-2 tropical maize inbreds. Crop Science 33: 1229-1234.

Scott MP, Bhatnagar S and Betran J (2004) Tryptophan and methionine levels in quality protein maize breeding germplasm. Maydica 49: 303-311.

Sezegen B and Carena MJ (2009) Divergent recurrent selection for cold tolerance in two improved maize populations. Euphytica 167: 237-244.

Vasal SK, Villegas E, Bjaranson MS, Gelaw B and Goertz P (1980) Genetic modifiers and breeding strategies in developing hard endosperm $\mathrm{O} 2$ materials. In Pollmer WG and Philipps RH (eds.) Improvement of quality traits of maize for grain and silage uses. Nijhoff, London, p. 37-73.

Vasal SK (1994) High quality protein corn. In Hallauer AR (ed.) Specialty corns. CRC Press, Boca Raton, p. 79-122.

Yang J, Carena MJ and Uphaus J (2010) AUDDC: A method to evaluate rate of dry down in maize. Crop Science 50: 1-8. 
